\title{
Refugees and Collective Action: A Case Study of the Association of Dispersed Guatemalan Refugees
}

\author{
Galit Wolfensohn
}

\begin{abstract}
The paper traces the organizational development of the Association of Dispersed Guatemalan Refugees (ARDIGUA), a grassroots, self-settled Guatemalan refugee organization, in an attempt to understand the dynamics of popular mobilization in exile. It examines the challenges faced by the more vulnerable and institutionally marginalized selfsettled refugees in their efforts to secure rights as refugees and as returning Guatemalans. It argues that the collective mobilization of self-settled refugees was facilitated by political opportunities external to ARDIGUA, as well as by resources-material and discursive-that the association mobilized. The paper draws attention to the role that selfsettled refugees can play as political actors in the wider process of peace and democratization, and argues that the impact of their efforts is significant (beyond their immediate material success) to the extent to which they articulate their traditionally marginalized concerns in politically and institutionally consequential forums. In this way, they contribute to the expansion and democratization of public discourse, and help to widen spaces in which the excluded can actively engage as social and political actors.
\end{abstract}

\section{Résumé}

L'article retrace le développement organisationnel de l'Asociación de Refugiados Dispersas de Guatemala (ARDIGUA), une organisation populaire de réfugiés guatémaltèques auto-établis, dans le but d'essayer de comprendre la dynamique de la mobilisation de masse dans l'exil. Il examine les défis auxquels eurent à faire face les plus vulnérables et les plus marginalisés des réfugiés dans leur tentative d'obtenir des droits en tant que réfugiés et en tant que guatémaltèques de retour au pays. Il propose la thèse que la mobilisation de réfugiés auto-établis fut favorisée par des conjonctures politiques externes à ARDIGUA, aussi bien que par les ressources matérielles et humaines que l'association parvint à réunir. L'article attire l'attention sur le rôle que peuvent jouer des réfugiés auto-établis en tant qu'acteurs politiques dans le processus élargi de paix et de démocratisation, et soutient que l'impact de leurs efforts est important et va bien au-delà de leur succès matériel immédiat. Cela est vrai dans la mesure où ils parviennent à exprimer clairement leurs préoccupations - qui sont traditionnellement marginalisées — dans des forums qui font réellement poids, politiquement et institutionnellement. Ce faisant, ils concourent à l'élargissement et à la démocratisation du discours public et aident à amplifier les espaces où les exclus peuvent prendre une part active en tant qu'acteurs sociaux et politiques.

$\mathrm{I}$ t was time to leave," recalled Maria-Jose Cartegena, ${ }^{1}$ a self-settled Guatemalan refugee in southeastern Chiapas. In the early 1980s, the violence had spread to the Guatemalan countryside. Villages were under siege, family members lay murdered, and the crops that were not yet burned to the ground were spotted with blood. A harrowing journey led hundreds of thousands of Guatemalans through forests and mountain pathways to the refuge of the Mexican border. In Chiapas, individual families were housed by distant cousins or generous acquaintances, until it was safe to return. Time passed, more families came. Most dispersed through the host population. To avoid deportation, they had to remain inconspicuous and find creative ways to survive. "We spoke, dressed, walked like they did, but raised our children with whispered stories of home. We found refuge from the violence, but were not officially recognized as refugees. We had no security, no documentation, no health care, no education, no land, and no future here. We kept watching and waiting for the right time to return." 
Self-settled refugees are de facto political refugees who have settled outside of official refugee camps. Unlike campbased refugees, the majority are not recognized as official refugees by the host state, or by national and international refugee organizations. ${ }^{2}$ This lack of legal status in the host country makes them vulnerable to deportation, and limits their access to social and economic resources, such as health services, education, and labour opportunities.

In 1992, the Association of Dispersed Guatemalan Refugees (ARDIGUA) emerged as the grassroots representative body of self-settled Guatemalan refugees in Mexico. Ardigua began to advocate for the rights of self-settled refugees to official recognition and documentation as refugees, and for their right to collective return to Guatemala. Ardigua was associated with the broader Guatemalan return movement, but was distinct from the leading campbased refugee organization, the Permanent Commission of Representatives of Guatemalan Refugees in Mexico (ССРP), because of its self-settled constituency, its related demands, and its independent organizational identity.

The participation of self-settled refugees in the Guatemalan return movement may seem surprising at first. By the very nature of their non-recognized status, they are even more marginalized from the official public sphere than camp refugees, and their legal vulnerability and dispersal make their propensity for collective mobilization extremely low. Yet, it is precisely this counter-intuitiveness that makes the case study of ARDIGUA noteworthy. In drawing attention to the generally under-represented, self-settled refugees, this study sheds light on their plight as well as on their potential to act as a political force. Furthermore, as much more is known about the return efforts of the highly publicized, camp-based CCPP, this case study contributes to a broader understanding of the dynamics of the return effort by drawing attention to this lesser known refugee group.

This paper briefly traces the organizational development of ARDIGUA with the interest of discovering what conditions facilitated the emergence and successful articulation of the association. In other words, rather than take the existence of and support for the popular self-settled refugee organization as a given, the paper explores why such formalized collective mobilization-of refugees generally and of self-settled refugees more specifically-occurred in the Guatemalan case and not in others. Following from this, the paper will assess the impact that refugee efforts had on both material and discursive realms.

To help frame this research, concepts are drawn from the literature on social movements, which attempts to make sense of the whys and hows of popular collective action (Escobar and Alvarez 1992; Foweraker 1995; Fraser 1993).
Using related analytical frameworks, this paper will argue that the viability of self-settled refugees to participate in the return effort was made possible by a combination of: political opportunities on local national, regional, and international realms that helped create political spaces wherein refugees could articulate their concerns in public forums; the ability of self-settled refugees to mobilize resources, both material and discursive, to meet their goals; and the existence of a support network of refugee-related actors, churches, and non-governmental organizations, that helped to grant public legitimacy to the association and its efforts.

This paper argues that the participation of refugees (both camp and self-settled) in the Guatemalan return effort challenged the Guatemalan state specifically and the refugee system more generally. This challenge was embodied in the popular-based refugee organizations that were the formal public expression of refugees as social and political actors, and was effected through the articulation of their demands (for a just and equitable return) in official public forums. This paper will argue, furthermore, that as a popular representative of sub-marginalized actors within this process, ARDIGUA's very existence subverted this marginalization and thus challenged those enforcing the exclusion of its constituency. Furthermore, understanding the return movement to be an example of how collective mobilization in exile can challenge the exclusionary practices of the state (and of the refugee system), this paper proposes that ARDIGUA's efforts (by the very nature of the association's sub-marginalized status), made these challenges more explicit.

While the extent of the material success of ARDIGUA's efforts is debatable, this paper concludes that ARDIGUA contributed to the expansion of discursive space by forcing the inclusion of the traditionally marginalized concerns of selfsettled refugees onto national and international agendas. In so doing, it contributed to a broader attempt to democratize institutionalized systems of exclusion.

\section{Context for Collective Action}

In 1987, Guatemalan refugees in camps throughout the Mexican states of Chiapas, Campeche, and Quintana Roo began organizing their collective return to Guatemala. Refugee representatives from each camp were elected to form the Permanent Commission of Representatives of the Guatemalan Refugees in Mexico (CCPP) — a body mandated to represent the interests of refugees to the Guatemalan government and international actors. The return effort was a collective, participatory, and secure alternative to the individually based, non-participatory, and insecure state-run 
repatriation program (Pritchard 1996; Aguilar 1991; CCPP 1992). It was informed by a wider political vision that saw refugees as social subjects contributing to peace-building and democratization in Guatemala (Arroyo 1995; Costello 1995; Pritchard 1996). In 1992, the CCPP signed the bilateral Basic Accord on Repatriation with the Guatemalan government, which laid the groundwork for implementing the collective return that was to follow. By June 1999, over 43 ,00o refugees had collectively returned to Guatemala from Mexico (CERIGUA 1999; USCR 2000).

The ССРP, which emerged from and was based within the camps, articulated the self-defined interests of the camp refugees. Yet camp refugees were not the only Guatemalan refugees in Mexico. In fact, over three times the 46,00o refugees who settled in camps throughout Mexico in the early 1980 s, settled outside the auspices of official humanitarian assistance. The majority of these self-settled refugees were not recognized as refugees by the Mexican government or by the United Nations High Commissioner for Refugees (UNHCR). ${ }^{3}$ They had no legal status in Mexico, had little access to international humanitarian assistance, and were vulnerable to deportation. These conditions led self-settled refugees to have concerns about protection and rights that were distinct from those of their camp brethren. Their legal vulnerability and dispersal made the propensity of selfsettled refugees to mobilize collectively extremely low (Salvado 1988; Chavarria et al. 1993; SERCATE 1993; Delli Sante 1996).

In 1992, bolstered by the initial success of the ССPP and fuelled by the division that plagued the CCPP leadership, ARDIGUA emerged as a distinct organizational body claiming to represent the interests of self-settled Guatemalan refugees in Mexico (Kauffer 1997; ARDIGUA 1998). The particular obstacles faced by this population, coupled with the political objectives of the elected leadership, informed ARDIGUA's two central demands. The first was to gain official recognition and related documentation as political refugees in Mexico. The second was to organize a collective return to the resource-rich (and thus expensive, coveted, and contested) south coast of Guatemala (ARDIGUA 1993, 1998; SERCATE 1993; Venet 1998). As ARDIGUA was not a signatory to the Accord on Repatriation, realizing its demand for collective return (which fell under the accord's provision) was not a given.

Ardigua used several strategies to overcome its marginalization from the return process and circumvent the obstacles erected by the Guatemalan government, which lay in the way of realizing its objectives. In order to understand these strategies, the conditions that facilitated them, and their material and discursive effects, the following analysis draws on concepts from the literature on social movements.

\section{Political Opportunities, ${ }^{4}$ Mobilizing Resources, and Social Networks}

ARDIGUA's emergence must be understood within the context of the wider movement for refugee return. The initial mobilization of camp refugees for return (beginning in 1987) was made possible in part through the political opportunities generated by regional and national shifts towards peace and democratization. The mid-1980s saw the initiation of regional efforts to secure peace in Central America through the promotion of coordinated strategies for negotiating peace, which pressured governments to resolve internal conflicts. Related conferences brought attention to refugee issues, presented some rights-based frameworks that could be used to address them, and created political opportunities for refugees to articulate their concerns as social and political subjects. On a national level, 1989 saw the Guatemalan government and civil society engage in a national dialogue (in which refugee representatives participated), and 1990 saw the government begin talks with the insurgent Guatemalan National Revolutionary Unity (URNG) (Arroyo 1995; SERCATE 1993; Aguilar 1991). These events, among others, marked a national shift towards peace and created opportunities for civil society actors, including refugees, to participate in the political transformation.

While these events had an indirect effect on ARDIGUA's emergence, it was the political opportunities generated by the initial success of the more central and publicly recognized CCPP project that encouraged the mobilization of more vulnerable self-settled refugees, and facilitated their articulation in the public sphere.

The establishment of the CCPP and its initial accomplishments widened political opportunities that helped mobilize other refugee groups and were necessary precursors to ARDIGUA's emergence. Through its legitimacy among refugees in the camps, the CCPP fuelled their support for the return project and initiated collective mobilization. This shifted the return from an idea to a concrete political project. Through its linkages with national and international actors, the CCPP established public legitimacy for the return project and gained access to consequential forums in which it formally articulated its demands. Through its linkages with civil society in Guatemala, it gained domestic support for the return and integrated itself as a refugee representative in the wider effort of national peace and reconciliation. And finally, through its negotiation with the government, which culminated in the formal acknowledge- 
ment of its demand in the Basic Accord on Repatriation, the ССРP secured tangible legal frameworks through which the return could be effected. Together, these successes established a precedent that other actors, such as ARDIGUA, could build upon to meet their own specific needs and concerns. These linked efforts of different popular refugee organizations illustrate the multiplier effect of popular action, and the interdependence of popular actors in their efforts to bring about change (McAdam 1998; Tarrow 1998).

While shifting political opportunities set the stage for collective action, it was ARDIGUA's success in mobilizing resources that helps to explain its ability to act upon such opportunities (Canel 1997).

In this vein, ARDIGUA's leadership (understood as both a resource and a mobilizer of resources), which was informed by a wider political agenda, played a central role in mobilizing the unlikely population (Alvarez 1997; Kauffer 1997; Briere 1998; Mosquera 1998). The leaders faced distinct challenges in their attempts to mobilize the self-settled population. Unlike camp refugees, who were spatially concentrated, highly visible, and legal, self-settled refugees were dispersed, legally vulnerable, wary of public attention, and distrustful. These variables distinguished ARDIGUA's strategies for mobilization from those of the CCPP. ARDIGUA used informal networks to identify and contact self-settled refugees. The early leadership travelled from house to house to meet with individual refugee families, to introduce the association's mandate and objectives, and to share information about the return effort. In this way ARDIGUA attempted to establish trust with the dispersed community and to promote an active interest in the return project (ARDIGUA 1998).

Balancing this leadership effort was the substantial role of ARDIGUA's constituency, which demanded accountable leadership and helped to define the interests of the association (Ramirez 1999). Facilitating this dynamic was ARDIGUA's relatively participatory organizational structure, which depended upon and actively encouraged the participation of the membership (ARDIGUA 1998, 1993; Horizons 1993). For example, member-based local and regional committees were driving forces behind ARDIGUA's efforts to identify and secure land for return.

ARDIGUA's collective identity paralleled that fostered by the CСPP, by infusing an ethnic and class consciousness with a claim to Guatemalan nationality (Aguilar 1991; Chaviarria et al. 1993; Pritchard 1996). Its distinction, however, lay in the substitution of a shared refugee identity with one that focused on the population's shared experience as self-settled non-documented refugees - an experience that included a constant fear of detection and deportation (Earle 1994;
Salvado 1988; Chavarria et al. 1993). This helped to foster a sense of collective solidarity, which was important for organizational unity. Furthermore, by literally bringing together the dispersed and legally vulnerable population (for example, through regional meetings), ARDIGUA helped to foster new links among individuals, which in turn expanded their collective sphere.

The group's shared experience in exile contributed to their collective interest in documentation and return, an interest that ARDIGUA successfully articulated in its demands and subsequent objectives. This shared vision strengthened the internal legitimacy of the association. Within the first two years of its establishment, ARDIGUA could boast an organizational presence in southeastern Chiapas and had extended its efforts to thirty-six communities (sERCATE 1993; Chavarria et al. 1993; Horizons 1993; ARDIGUA 1998).

The effective public articulation of ARDIGUA's objectives became significant in establishing legitimacy with external actors (which included international organizations, governments, non-governmental organizations, church groups, civil society actors, and other refugee organizations). ARDiguA's exclusion from the institutional sphere, however, required that it adopt strategies distinct from those of the CСPP to make its claims heard. It began by linking its demands to those of the ССРP and the wider return, but modified them slightly to meet its own interests (for example, ARDIGUA was adamant about securing a return to the resource-rich south coast of Guatemala, whereas the CCPP negotiated returns to a variety of regions in the country, many of which were isolated and underdeveloped). As with the CCPP, ARDIGUA expressed it demands in the context of human rights and appropriated institutional labels to articulate its claims in the public sphere (Stepputant 1994). Rather than adapting the "refugee" label, however, the association appropriated the label of "non-recognized refugee," which it then recast as one portion (rather than the central feature) of the self-settled population's identity. In place of this negative identity, ARDIGUA identified spatial dispersal as the primary identifying feature of the disperso population.

The response of external actors to ARDIGUA was mixed. ArdiguA's direct relationship with the Guatemalan government was characterized by government recalcitrance, not unlike that directed against other refugee groups. Such resistance was largely due to extreme pressures put on the government from the Guatemalan landholding elite and the military, both of which saw the returning refugees as a threat to their established power (Costello 1995; Briere 1998; SERCATE 1993). That ARDIGUA demanded a return to the more contentious south coast of Guatemala simply made 
these pressures more extreme, and the association's marginality made it easier for the government to forestall its efforts.

Ardigua's ability to pursue its objectives in the face of such obstacles was realized in large part through its ability to establish linkages with a support network of refugee-related actors. ${ }^{5}$ Its closest and perhaps most dependent link was to the CCPP, because it was the sole signatory to the Accord on Repatriation, and for a long time the only organization working with refugees that the Guatemalan government agreed to recognize (Briere 1998). As such, its cooperation was essential for ARDIGUA to gain access by proxy to the official forums from which it was excluded.

The Church, non-governmental organizations (NGOS), and other civil society actors, in Mexico as well as in Guatemala, also lobbied on behalf of ARDIGUA and pushed for recognition of its concerns in more consequential forums (Aguilar 1991; Horizons 1993; SERCATE 1993; Arroyo 1995; Venet 1998). International and transnational actors also played a prominent role in facilitating ARDIGUA's efforts by providing it with material resources, ${ }^{6}$ and by putting diplomatic pressure on the Guatemalan government to meet and conclusively negotiate with the association.

ARDIGUA faced greater challenges than the CCPP in forging organizational relationships and gaining public legitimacy. The ccpp's advantage was partly due to its direct access to and interaction with NGOS and international agencies, such as the UNHCR, that worked with the camp population. This relationship helped to foster mutual familiarity and trust, and provided the CCPP's constituency with access to material resources and training workshops, which helped them hone the skills in leadership and negotiation. While ARDIGUA was admittedly marginalized from the more formal of the institutional actors, such as the UNHCR, it did garner limited recognition from them, which aided in its efforts to negotiate with the state (Venet 1998; ARDIGUA 1998).

\section{Material and Discursive Impacts}

ARdigua succeeded in realizing one - but not both—of its central demands. By 1999, approximately 750 ARDIGUA members had secured a collective return to the south coast of Guatemala. The self-settled membership remaining in Mexico, however, never received official state recognition or proper documentation as refugees.

Many argue that the substantial success of ARDIGUA's efforts was negligible, because of its failure to secure documentation for the population, and the relatively small number of ARDIGUA returns-as compared to the tens of thousands of refugees who returned under the widely publicized auspices of the CCPP. The latter discrepancy in num- bers can be explained by the vulnerable status of ARDIGUA's population base, which discouraged many from mobilizing under the ARDIGUA banner; the protracted delays that ARDIGUA faced in the land negotiations, which led exasperated members to seek alternative means of return; and the 1999 decision of the Mexican government to grant Guatemalan refugees permanent resident status in Mexico, which led many refugees to opt out of the return altogether.

While ARDIGUA's substantive success may have been limited, it should not detract from the non-material effects of popular collective action on the widening of discursive space. And it is precisely in this realm that ARDIGUA's efforts can be understood as radical (Escobar and Alvarez 1992; Fraser 1993; Alvarez 1997; Arato and Cohen 1997). In articulating its demands from its marginalized position, ARDIGUA was presenting a greater challenge (consciously or incidentally) to the status quo than the more publicly recognized camp refugees. More specifically, by demanding that non-recognized refugees be recognized as political refugees, ARDIGUA directly challenged the Mexican and Guatemalan governments, which had an interest in officially ignoring this population. It also posed an indirect challenge to the UNHCR, which, despite its protection mandate, was limited by diplomatic considerations in its ability to address the needs of this population. Finally, by making claims to return to the more developed south coast of Guatemala, ARDIGUA was posing a direct challenge to the landholding oligarchy in the region, and to the systemic racist and classist-informed exclusionary practices that deprive the majority of Guatemalans from exercising their full social, political, economic, ethnic, cultural, development, and citizenship rights.

\section{Discussion and Conclusion}

The collective mobilization of self-settled refugees around the issues of documentation and return, as examined in this case study, is unique to the extent to which self-settled refugees-as social and political subjects-were able to enter into consequential forums to make their claims heard and be partially accommodated by the state. It is also unique to the extent that such an expression of agency was formalized in the organizational body of ARDIGUA.

This uniqueness, however, is grounded in the formalization of these efforts, rather than in the efforts themselves. The subject of this case study is significant beyond its immediate context because it draws attention to the ability of refugees-self-settled or otherwise-to articulate agency and resistance in the interest of immediate or longer-term objectives. The focus on collective agency draws attention to the dynamics of popular collective mobilization more 
generally, as well as to the conditions of collective action in the displacement context more specifically. That the focus of this study is self-settled refugees-who have a lower propensity to mobilize collectively and tend to be more estranged from the institutional sphere-makes the marginalization of the popular subject explicit, and their struggle more contentious.

Ardigua's emergence from within the context of the wider return effort-itself a result of collective actiondraws attention to the potential cumulative effect of popular mobilization efforts, and their ability to widen political opportunities through which parallel or more vulnerable popular actors can emerge. Finally, as with the return movement more generally, ARDIGUA's efforts were political, and part of wider efforts to contribute to peace and political transformation in Guatemala. In this sense, this case study also illustrates the significant role that refugees can potentially play as political actors in extended processes of social and political change.

Several issues arose from this study that were not addressed here, but deserve attention and can serve as the basis for future research. One is the longer-term challenges of return, which is not as an end in itself, but a step in an extended process of reception, reintegration, and long-term development. Studies have been conducted on the challenges faced by return communities in Guatemala, which include tensions within the return settlements as well as conflicts between the returnees and the receiving population. The viability of the long-term development and integration of such settlements into the surrounding social, political, and economic landscape remains to be seen.

A related point of interest is the extent to which the organizational experience of ARDIGUA can translate into the Guatemalan context: What role, if any, can ARDIGUA play as an organizational entity in the domestic context? And to what extent will the experience of mobilization affect the continued involvement of ARDIGUA's members as active citizens, now that they have returned?

For those refugees who stayed in Mexico, other issues arise. Those who gained permanent status in the country face the challenges of integration, particularly in the face of diminishing international presence and related assistance for this process. For refugees who remain undocumented, their vulnerability may in fact increase, given that the refugee question is coming to formal resolve, and may make their exclusion from official return or integration efforts permanent.

What can other refugees learn from the Guatemalan return experience? What lessons can NGOs, international or- ganizations, and donors learn about promoting and/or facilitating the participation of refugees in future repatriation efforts? Perhaps future research can draw a comparative analysis of refugee collective action in different countries, to provide general answers to such questions. Such a study could broaden the understanding of refugees as significant social and political actors who can participate in and shape political processes.

ARDIGUA's efforts may spark further interest in the littlestudied realm of self-settled refugees, and in the broader social, political, and economic contexts that lead to and shape their experiences in exile. Its efforts may also generate interest in the collective role that they and other displaced persons can play to reappropriate spaces from which they have been marginalized and assert their "right to have rights."

\section{Endnotes}

1. Not her real name.

2. While not all self-settled refugees lack official refugee status or documentation, the majority of them do. Reference to self-settled refugees here will refer to those refugees with non-recognized refugee status, and the terms self-settled, non-recognized, undocumented and dispersed refugee will be used interchangeably.

3. If they were recognized at all by the Mexican government, it was usually as economic migrants, a status that refuted the political nature of their flight and the persecution they suffered.

4. See Tarrow 1998, McAdam 1996, and Schultz 1998.

5. Refugee-related actors include international humanitarian organizations, government refugee agencies, local non-governmental organizations, and churches that work directly with displaced communities by providing social services and advocating. Such actors include other grassroots refugee organizations.

6. For example, the European Commission funded projects, the UNHCR provided ARDIGUA with identity documents as well as limited funds to travel to Guatemala during the negotiations, and Horizons of Friendship helped run organization and human rights workshops.

7. The opportunity to claim permanent residence in Mexico did not have a dramatic impact on the decisions of self-settled refugees to opt out of the return, because many did not consider the government's proposal a viable option. Many presumed that having refugee documents, which they lacked, was a precursor to acquiring permanent resident status, and many more distrusted the government and remained wary of identifying themselves publicly, despite its promises.

\section{Bibliography}

Aguilar Zinser, Adolfo. "Repatriation of Guatemalan Refugees in Mexico: Conditions and Prospects." In Repatriation under Conflict in Central America. Edited by Larkin, Cuny, \& Stein. Washington, DC: Centre for Immigration Policy and Refugee 
Assistance, Georgetown University, 1991. -. 1998.

Alvarez, Sonia E. "Reweaving the Fabric of Collective Action: Social Movements and Challenges to 'Actually Existing Democracy' in Brazil." In Between Resistance and Revolution: Cultural Politics and Social Protest. Edited by Richard G. Fox and Orin Starn. New Brunswick: Rutgers University Press, 1997.

Arato, Andrew \& Jean Cohen. "Civil Society and Social Theory." In Between Totalitarianism and Postmodernity: A Thesis Eleven Reader. Edited by Peter Beilharz, Gillian Robinson, and John Rundell. Cambridge: MIT Press, 1997.

Arroyo, Iliana Yaschine. Un Hecho Sin Precedentes: Las Negociaciones y el Acuerdo Para El Retorno Entre el Gobierno de Guatemala y Los Refugiados Guatemaltecos en Mexico. Tesis para el Licenciado en Relaciones internacionales, El Colegio de Mexico, July 1995. Asociacion de Refugiados Dispersos de Guatemala (ARDIGUA). Programa de Desarrollo de la Asociacion de Refugados Guatemaltecos Dispersos. 1993.

- La Siembra: Buletin Informativo de ARDIGUA, GuatemalaMexico 4-6 (1998).

- Eusebio Jeronimo Pablo, Executive Committee member, Rumualdo Juarez Cabrera, representative member, José Domingo Ordonez, representative member, Maria Juarez Cabrera, representative member. Interview by author. Motozintla, Chiapas, Mexico, August 24, 25, 1998.

Briere, Nathalie. Project Accompaniment. Interview with author. San Cristobal de las Casas, Chiapas, Mexico. August 15, 1998.

Canel, Eduardo. "New Social Movement Theory and Resource Mobilization Theory: The Need for Integration." In Community Power and Grassroots Democracy: The Transformation of Social Life. Edited by M. Kaufman and H. D. Alfonso. Atlantic Highlands, NJ: Zed Books, 1997.

CERIGUA. CERIGUA Weekly Briefs 2 (January 14) 1999.

Chavarria, Samaria, and Barki J. Tacatic. Diagnostico Sobre Refugiados: Retornados y Desplazados de Guatemala. August 1993.

Comisión Permanente de Refugiados (CCPP) (Permanent Commission of Guatemalan Refugees in Mexico). Bulletin. 1992.

Costello, Patrick. Guatemala: Displacement, Return and the Peace Process. UK: WRITENET Country Papers, unHCR.ch/refworld/ country/writenet/wrigtm.htm, April 1995.

Delli Sante, Angela. Nightmare or Reality: Guatemala in the 1980 . Amsterdam: Thela Publishers, 1996.

Earle, Duncan M. "Constructions of Refugee Ethnic Identity: Guatemalan Mayas in Mexico and South Florida." In Reconstructing Lives, Recapturing Meaning: Refugee Identity, Gender and Cultural Change. Edited by Linda A. Camino and R. M. Krulfeld. Washington: Gordon and Breach Publishers, 1994.

Escobar, Arturo, and Sonia E. Alvarez, ed. The Making of Social Movements in Latin America: Identity, Strategy and Democracy. Boulder: Westview Press, 1992.

Foweraker, Joe. Theorizing Social Movements. Boulder: Pluto Press, 1995. Fraser, Nancy. "Rethinking the Public Sphere: A Contribution to the Critique of Actually Existing Democracy." In The Phantom Public Sphere. Edited by Bruce Robbins. Minneapolis: University of Minnesota Press, 1993.
Horizons of Friendship. Report on Guatemalan Return. Cobourg, Ontario, 1993.

Kauffer, Edith Françoise. Doctorado en Ciencias Políticas por el Instituto de Estudios Políticos de la Universidad de Aix-Marseille, 1997.

McAdam, Doug. "Conceptual Origins, Current Problems, Future Directions.” In Comparative Perspectives on Social Movements: Political Opportunities, Mobilizing Structures and Cultural Framings. Edited by Doug McAdam, John D. McCarthy, and Mayer N. Zald. New York: Cambridge University Press, 1996.

Mosquera Aguilar, Antonio, former legal advisor, Asociacion de Refugiados Dispersos de Guatemala (ARDigUA). Interview by author. San Cristobal de las Casas, Chiapas, Mexico, August 15, 1998.

Pritchard, D. “The Legacy of Conflict: Refugee Repatriation and Reintegration in Central America." In Central America: Fragile Transition. Edited by R. Sieder. London: Macmillan Press, 1996.

Ramirez, Andres, United Nations High Commission for Refugees. Telephone interview by author. New York, April 1999.

Salvado, Luis Raul. The Other Refugees: A Study of Nonrecognized Guatemalan Refugees in Chiapas, Mexico. Washington: Centre for Immigration Policy and Refugee Assistance, Georgetown University, 1988.

Schultz, Markus S. "Collective Action Across Borders: Opportunity Structures, Network Capacities, and Communicative Praxis in the Age of Advanced Globalization." Sociological Perspectives 41 (3): 587-616.

Servecios de Capacitacion Tecnica y Educativa (sercate). Los Caminos Del Exodo y Retorno del Refugiado Disperso: Parte IUna Historia de Persecucion y Sobrevivencia. Guatemala, C.A.: Impresion Infopress Centroamericana, 1993.

Stepputant, Fin. "Repatriation and the Politics of Space: The Case of the Mayan Diaspora and the Return Movement." Journal of Refugee Studies 7 (2/3): 175-85.

Tarrow, Sidney. "Social Protest and Policy Reform: May 1968 and the Loi d'Orientation in France." In From Contention to Democracy. Edited by Marco G. Giugni, Doug McAdam, and Charles Tilly. Maryland: Rowan \& Littlefield Publishers Inc., 1998.

uscr. Country Report: Guatemala. <http://www.refugees.org/world/ countryrptamer_carib/guatemala.htm $>, 2000$.

Venet, Fabienne, general director of Sin Fronteras. Interview by author. Mexico City, Mexico. August 1998.

Galit Wolfensohn is working with the Project on Internal Displacement at the Brookings Institution in Washington, $D C$, and previously worked with a variety of humanitarian and social justice organizations. This paper is a condensed version of the major research paper she completed in 1999 as part of a master's in Refugee and Environmental Studies from York University, Toronto. 